\title{
The Disappearance of Sophia Frances Hickman, M.D.
}

At lunch time on 15 August 1903, Dr Sophia Frances Hickman left the Royal Free Hospital and did not return. She had begun a fortnightly stint as a locum the day before and the absence was entirely uncharacteristic of this dedicated, prize-winning former student of the London School of Medicine for Women (LSMW). Now totally forgotten about, Miss Hickman's disappearance led, in fact, to one of the most prominent missing person investigations of the early years of the twentieth century. ${ }^{1}$ As family, friends and police searched the length and breadth of Britain for Miss Hickman, doubts began to be voiced about this evidently mentally and physically strong woman, who had blithely deserted her post and, ultimately, her responsibilities as a qualified professional. Not only was her own reputation questioned, but also, by extension, that of her sex, in coping sufficiently with the expectations and pressures of medical practise. Press scrutiny into their capabilities encouraged medical women publicly to defend themselves and their aptitude as practitioners. The Hickman Case led to the re-emergence of debates female doctors had imagined long past. Half a century previously, their mental, physical and moral capacity to act as members of the medical profession had been questioned by male colleagues and the public alike. Many dismissed their ambitions as the fantastic aberrations of excitable feminine minds. By the time the Great War began, however, the numbers of registered medical women had reached nearly one thousand from a paltry two forty years before. ${ }^{2}$ And yet there was no strength in numbers, when fitness to practise was precisely the accusation, in the light of the Hickman case, levelled at medical women.

'No disappearance for so many years past has so touched the imagination of the nation' proclaimed the Daily News in October $1903 .{ }^{3}$ In this article, I want to explore how and why the disappearance of a 'lady doctor' stimulated the national imagination in the ways it did, as well as examining reactions from the lay and medical press to the case itself and to the 
wider issues it raised. Nearly quarter of a century after the furore over Miss Hickman, in a section of his 1927 book, From Clue to Dock, entitled 'Mysteries that Have Puzzled the World', C.L. McCluer Stevens discussed 'The Lost Lady Doctor'. About whom, he remarked, it could be claimed that it 'is doubtful whether any happening of the kind in modern times has created quite so big a sensation as did [her] disappearance in London, during the summer of 1903'. ${ }^{4}$ For McCluer Stevens, as well as for many others, the disappearance of Miss Hickman was a 'tragedy', but, ultimately, it was 'one of London's many unsolved mysteries'. 5 Due to the publicity generated by the family of the missing woman, alert to the ways in which contemporary press agencies could be utilised to sell reports to local newspapers all over the country, the case exorcised the British, and, indeed, the colonial, public in the summer and autumn of $1903 .{ }^{6}$ It emphasised the reach and power of the early twentieth-century press, yet it also showed that, even with country-wide attention, someone could vanish without a trace. Press and public alike were forced to speculate, without concrete evidence, on why Sophia Frances Hickman left her post. Although they were initially managed by the Hickman family version of events, theories abounded. Amongst all the rumours, it became evident, however, that very real anxieties about professional women had not evaporated nearly fifty years after they had emerged. While there is no possibility of solving this 'mystery' over a century after it occurred, tracing developments in the case allows the historian to gauge Edwardian responses to fallibility - whether that be female, medical or a combination of the two.

Sophia Frances Hickman was twenty-nine years old when she vanished in 1903. She had studied at the LSMW between 1897 and 1902. The LSMW had been established in 1874 to allow those women who had been barred from obtaining a medical education elsewhere in Britain to study in an environment where they need not face opposition because of their sex, and, of course, to allow them to pursue that education in the first place. 
Four years later it had joined forces for clinical instruction with the Royal Free Hospital, then situated in Central London on Gray’s Inn Road. ${ }^{7}$ The Royal Free was, therefore, well known to Miss Hickman, who would have spent the second part of her degree on its wards. Sophia Hickman excelled academically at the LSMW. As a meeting of the Council of the School noted, while only qualified recently, Miss Hickman 'gave promise of very excellent work' ${ }^{8}$ Indeed, when she first disappeared, her bewildered father, merchant E.F. Hickman, wrote to a number of daily newspapers with a description of his daughter, as well as a list of her impressive academic credentials. She had gained honours in materia medica (1897); in physics and chemistry, with prizes, and in anatomy and histology (1898); in physiology and anatomy (1899); in midwifery (1900); in medicine, with a prize, and surgery and operative midwifery (1901); and, in 1902, in midwifery, with a prize, and in pathology. First-class honours concluded her undergraduate career. A Brussels MD degree had followed, along with an appointment as a junior resident medical officer at the Battersea branch of the Clapham Maternity Hospital, in South West London. ${ }^{9}$ Miss Hickman succeeded in gaining honours in every year of her degree, as well as across most subjects studied at this point. This was indeed rare, as was the completion of a medical degree in five years; a feat achieved 'only by a few'. ${ }^{10}$ The pride in her achievements was evident from her father's touching letter. But, as the British Medical Journal warned in February 1902 when it considered the question as to whether, in America, the medical woman was 'A Failure':

For the practice of medicine much more than the power of passing examinations is required. To the making of a successful doctor there must go qualities of head and heart that cannot be tested by examination. And all these are vain unless they are accompanied by physical vigour. ${ }^{11}$

To this 'incommunicable knowledge', which could not be examined, practicality and tolerance in the face of adversity were fundamental. ${ }^{12}$ Even if women like Miss Hickman 
could 'pass examinations', remarked the $B M J$, other strengths were wanted to be a successful practitioner of medicine.

Fitness to practise dominated early debates about women's suitability for the rigours of the medical profession. At the end of 1916, the student magazine of the LSMW looked back from the medical woman's achievements of the early twentieth century to a time fifty years before when female practitioners were imagined 'too nervous, too emotional, too wayward and too fitful to stand the discipline required'. ${ }^{13}$ Neither were they likely to cope with the visceral nature of the job. The sight of blood would inevitably cause consternation and, if it all became too much, they might simply faint. Opponents of women's campaign to enter medicine utilised female weakness in all aspects of life as the essential reason why they should not succeed in their aims. ${ }^{14}$ Sophia Frances Hickman, however, was certainly not lacking in mental and physical robustness. Indeed, in the search for her, the latter, especially, dominated descriptions. At five foot nine, Miss Hickman was certainly distinctive, standing head and shoulders above her female, and even her male, contemporaries. When offering a physical portrait of his daughter, E.F. Hickman noted her striking figure:

I shall feel very grateful to you if you will kindly give the utmost publicity about her. The following describes her: 29 years of age, about $5 \mathrm{ft} 9 \mathrm{in}$ high, of a powerful build, fair, light brown hair, worn on the sides of her high forehead, large grey eyes, full lips, red and healthy complexion, clad in a blue blouse with a very large turn-down collar open at the neck, and it is thought she wore a dark blue alpaca walking skirt, no corset, a white and black hat, and large shoes. She is a splendid walker, fond of Wimbledon Common, Coombe Wood, Richmond, and the country generally. ${ }^{15}$

If women were assumed initially to be too mentally and physically fragile to become doctors, 'the physical fatigue' of daily medical life also disqualified them from practise. They were 
simply ill-adapted to the hardiness expected of a profession at the beck and call of patients all times of the day and night and all year round. ${ }^{16}$ By the early twentieth century, women such as Sophia Hickman, with their hale and hearty attributes had proved doubters wrong. What dominated the image of the missing woman was her strength, vigour and confidence; hardly the sort to desert her post and vanish. Yet, in spite of her lack of corsetry and love for outdoor pursuits, Miss Hickman, for the press, had not lost her femininity. The engraving circulated with her description reveals, as Joan and Jill in 'Our Ladies' Letter' for the Reading Mercury claimed, 'an attractive face, with both sweetness and commonsense combined'. ${ }^{17}$ In the early press reports concerning her disappearance, with information provided by family and friends, Sophia Hickman was presented as embodying the ideal medical woman. She combined physical and mental fitness, in addition to her feminine nature; she was academically brilliant, but with a love for exercise and healthy recreation.

According to her proud father, Miss Hickman was dedicated to her profession and selflessly devoted to her patients. She not only assisted them medically, but continued her interest in them after consultation hours. Previous to her post at the Royal Free, Miss Hickman had spent six months at the Battersea Branch of the Clapham Maternity Hospital. Concerned by the poverty she witnessed all around her - 'many of her patients were on the verge of starvation' reminds her father - 'every day she assisted her sister and others in making and distributing soup for them, and in other ways providing for their wants' ${ }^{18}$ Her commitment went beyond the call of medical duty, as she interested herself in patients' home lives and in their physical needs, dispensing charitable donations to the needy. Neither was Miss Hickman scared of, or by, very difficult or dangerous surroundings; her 'devotion' to the poor was marked by her willingness to enter their homes 'freely' and without concern for her safety. As Margaret Joyce, a colleague at the Battersea branch, made clear, her friend was always 'very cheerful', healthy and well rested, in spite of the 
'severity' of work which required many external visits, long hours and night shifts. ${ }^{19}$ For friends, colleagues and family members, Sophia Frances Hickman maintained a successful balance between her professional and private lives, by working hard, but without overstraining or destroying her health. Given the contemporary fear about the propensity for the student or young, middle-class female to overwork, such common sense was admirable. $^{20}$ Equilibrium in all things was the motto of this medical woman. That she might have abandoned her post, leaving both the hospital and its patients without support, was unthinkable for those who characterised Miss Hickman as dedicated to improving the lives of others.

But leave her post she had. From the day of her disappearance, speculation mounted as to why an apparently happy, contented woman had simply vanished without a word to anyone. E.F. Hickman, perplexed at the sudden turn of events, was quickly able to pinpoint a reason why his 'dear daughter' might have abandoned her colleagues and place of work within a day of taking up her new post. He placed the blame squarely at her employer's door. The Royal Free Hospital was located in the centre of the city on Gray's Inn Road; it was not until the 1970s that it moved to the more salubrious Belsize Park in North-West London. While the hospital took only female students for clinical training, linked as it was with the LSMW, and employed female alongside male doctors, the patients were certainly not those with whom a well-brought up, middle-class lady would usually associate. The Magazine of the LSMW frequently retold tales of 'Gate', the nickname for the casualty department at the Royal Free, where LSMW students would have their first experience of clinical work. These stories were a combination of gentle mockery at patient Cockneyisms and hints at something a little less pleasant. In 1903, 'Gate' treated 24,470 casualties; only 3,844 of these were minor injuries. ${ }^{21}$ While the RFH was not a large hospital, its location meant that it received its fair share of metropolitan emergencies; its young, female student 
dressers and clerks would have been thrown headlong into the aftermath of catastrophic industrial and street accidents, as well as more mundane injuries. A 1907 poem submitted to the Magazine refers to the 'sorry septic line' of patients appearing at 9am. Twelve hours later, things have not improved for the weary medical attendants:

A stretcher from the station

With a ghastly mutilation,

And the usual host of minor aches and pains.

How the drunks beset the door!

Singing loud above the roar,

As babies raise a protest, lying trampled on the floor.

Oh this Gate we stand to hold

Is no shiny Gate of Gold,

But the Way of Peace to dressers when the evening shift is o'er. ${ }^{22}$

In 1902, another student remarked on the 'squalor and limited space' of Gate. ${ }^{23}$ The noise and disorder, the 'ghastly' sights and smells of a central London casualty department made the experience of Gate a baptism of fire for the fledgling medical woman.

When questioned as to why he felt his daughter might have disappeared, E.F. Hickman repeatedly mentioned her experience at the Royal Free Hospital, especially the prospect of "“distasteful"" Gate duty, as probably leading to her flight. ${ }^{24}$ From the moment she vanished, attention was thus directed towards the responsibilities of young, and especially female, medical practitioners on the wards of such an institution. Another side also began to emerge of a woman whose moral scruples prevented her from caring so acutely for those who might have brought illness and injury upon themselves. Sophia Hickman's departure, before the consequences of pay day excess wandered in, was surely no coincidence, proposed her father: 'I believe the sight of so many great sufferers at the Royal Free Hospital 
and the anticipation of having to attend so many dreadful cases that present themselves of a Saturday evening upset her nerves and caused her to seek rest elsewhere'. ${ }^{25}$ Within a few days of her disappearance, Miss Hickman's flawless image was already beginning to crack. Rather than possessing the steady nerves and calm manner suggested by all who knew her, Sophia Hickman had potentially deserted her post because she felt unable to cope with the more difficult cases, rendered more complex and dangerous through intoxication. With such an angle on the reasons for Miss Hickman's disappearance, the institutional context also came in for scrutiny. The light-hearted tone of the 'Gate' poem with its drunks bearing down upon the hospital certainly takes on a more sinister tone when considered alongside the fears which may have been experienced by Sophia Hickman and others like her when on duty there.

The scandalmongering press agencies, prompted by Mr Hickman's concerns, descended on the RFH, eager to sell stories by finding dissension in the ranks of the supposedly united professional band of 'lady doctors'. Mr Hickman had presented such an idealised image of his perfect child that some were determined to look for the surely more mottled reality. If Miss Hickman had been unhappy in her work, then, inevitably, a colleague would know more about it? The Central News Agency thought it had discovered the reason behind Miss Hickman's sudden departure when it distributed an interview with Miss Chamberlain, who was working as a house physician at the Royal Free at the same time as the missing woman. This interviewee happened also to be related to the present Colonial Secretary, Joseph Chamberlain, which added interest to the tale, as well as an undoubted increase both in veracity, as the agency saw it, and, to put it more cynically, in sales figures. The story was taken up by The Star, to give one example, on 28 August, a fortnight after Miss Hickman had last been seen. It was subtitled with the promise of revealing 'Why Miss Hickman Left the Hospital' and continued with the news that she "'had come into conflict with one of the 
lady doctors on the staff", ${ }^{26}$ From the outset of the female agitation to join the medical profession in the mid nineteenth century, women doctors were very keen to suggest their unified stance in the face of considerable opposition from many male colleagues. Having been students at the LSMW, both Sophia Hickman and Katherine Chamberlain would have been inculcated throughout their education about the necessity of presenting a united front. They would have also been encouraged to acknowledge the unbroken line of female medical success from the pioneering generation to the present day and the debt they owed to their embattled predecessors. ${ }^{27}$ Fissures which had begun to open up between 'lady doctors' at the start of the twentieth century were magnified by the Central News' direct attacks. The most prominent division was between the increasingly differing outlooks of largely older and more separatist medical women and their younger counterparts, who were keen to work alongside, rather than fight, their male colleagues. ${ }^{28}$ It transpired that the problem alleged to have occurred between Hickman and Chamberlain was simply a dispute over the time the former could sit down to lunch. Yet these revelations, coupled with his firmly-held belief in the terrors to be faced on 'Gate', led to a campaign by Mr Hickman to force the Royal Free to hold an enquiry into the circumstances surrounding his daughter's disappearance. As a result of this public pressure, the hospital was compelled to mount an equally vigorous defence both of its practices and its own staff.

A Special Meeting held by the Weekly Board of the Royal Free Hospital on Thursday, 3 September 1903 was ostensibly called to deal with Mr Hickman's repeated public calls for an enquiry. These had become increasingly loud and prominent in his correspondence with The Times and had focused attention upon the hospital as a source for Miss Hickman's disappearance. A response to the Central News' accusations of conflict had already been produced by one of the staff, senior resident medical officer, Joseph Cunning, who sparked off a debate in the Times. Cunning, writing '[o]n behalf of the hospital', lambasted the news 
agency's 'invent[ions]' and 'imagin[ings]' about Miss Hickman's fleeing the Royal Free 'in consequence of a quarrel with a colleague': 'There is not the slightest foundation for such a story save in the imagination of the person whose pen ran riot with his veracity'. Denying there had been 'friction', or 'admittance' of any disagreement on the part of Miss Chamberlain, Cunning thundered that the false report could 'only obscure inquiry by raising unpleasantness'. ${ }^{29}$ Cunning's tone was inflammatory and extremely defensive, and, unsurprisingly, a representative of the Central News Agency responded immediately. ${ }^{30} \mathrm{~J}$. Percy Watson, who had written the report distributed across the country by the Agency, replied in an equally high-pitched timbre. Watson threatened libel and revealed his sources for the article, which included an indirect intimation from the police, partial, then further confirmation from relatives, and, of course, the interview given by Miss Chamberlain. The report was, consequently, 'absolutely correct'. With such a stark statement appearing in one of the most respected dailies, it is no wonder that the Hospital called a 'Special Meeting' only one day after its usual gathering.

Charles Burt, the Treasurer and Chairman of the Hospital Weekly Board, had written to the Times straight after J. Percy Watson's letter had appeared, to reassure the public that the Royal Free Hospital was doing everything it could to assist the police in tracking down Miss Hickman. Burt also reiterated that the hospital had no intention of concealing any dispute, simply because there had never been any disagreement between members of the female staff in the first place. He had interviewed personally everyone who had seen or worked with Miss Hickman that Saturday morning, including nurses and students, and could only stress that the missing woman had been 'in good spirits, bright and cheerful, and fully attentive to her work in the wards, and that she showed no sign whatever of annoyance, unhappiness, or anxiety' ${ }^{31}$ In other words, Miss Hickman was her usual, professional self and only friendliness and cordiality existed between colleagues. Also published in the same edition 
of the Times, however, was a letter from E.F. Hickman, a copy of one submitted to the Royal Free itself. Hickman was determined to expose any shirking on the part of the Hospital, over responsibility for his daughter's disappearance and his private letters invariably ended up in print. Calling for the result of any enquiry to be 'made known to the public through the medium of the newspapers', Mr Hickman drew attention to the fact that his daughter was not remunerated for her position at the Royal Free. The honorary post in a voluntary hospital was a standard feature of a medical career before the formation of the National Health Service. Incomes were derived from private practice, but could be supplemented by experience gained without payment at general or specialist institutions, depending on the individual's interests. Positions were not easy to come by because competition was fierce and women were excluded from many general institutions by virtue of their sex alone. ${ }^{32}$ That medical staff were unpaid may not have been known by many early twentieth-century lay readers. E.F. Hickman, therefore, exposed both the difficulties of gaining a foothold in the profession and the expectation that his daughter was 'owed' something by the hospital, which had employed her gratis. ${ }^{33}$

The Royal Free management were clearly affected by the adverse publicity they had been receiving daily in the press. Their concern is patent when the historian investigates what happened behind closed doors, away from press curiosity. Archival records of Weekly Board meetings from August to October of 1903 are frequently supplemented with relevant newspaper articles. Mr Hickman's pressure encouraged a thorough search of areas of the hospital where the missing woman had been and an encouragement of all who had encountered her during her brief appointment to tell everything they knew. Miss Chamberlain denied that there had been any unpleasantness whatsoever in her relations with the missing woman. Press reports, she reiterated, were simply untrue and had not been warranted by anything she had said when questioned. The dissension was manufactured in 
an attempt to find a reason for a disappearance which few could understand; medical women, still evidently too few and too rare to be accepted, were an easy target. Interviews with other members of staff brought a number of previously unknown facts to light. ${ }^{34} \mathrm{~A}$ medical student, Miss King, who had been on holiday for a couple of weeks since the middle of August, had actually seen Sophia Hickman heading towards Holborn at 1.15 on the afternoon of the day she had disappeared. Equally revelatory was the discovery of a waterproof belonging to the missing woman. This had been left on another member of staff's peg, either deliberately abandoned by its owner, or an indication that she was due to return and collect it, but had been prevented in some way from so doing. While the information was passed on to the police, it sparked another flurry of letters from $\mathrm{Mr}$ Hickman, accusing the hospital of obstructing attempts to discover his daughter's whereabouts. The matter of an enquiry was discussed, but rejected, as an unwarranted and unnecessary interference with official proceedings. However, the hospital did make the decision to issue a reward of $£ 100$ for information leading to the discovery of Miss Hickman and to print bills to advertise this. When over one thousand of these had already been produced, Mr Hickman wrote to the Board with a cheque matching the Hospital's contribution. Due to the fact that they could not change the publicity, this cheque was rejected, and advice that correspondence with Mr Hickman be discontinued was accepted. However, the doubled reward was eventually advertised and further letters from $\mathrm{Mr}$ Hickman were replied to throughout the months of September and October. Unlike the Royal Free Hospital, E.F. Hickman had a more thorough knowledge of the ways in which the contemporary press operated and utilised them far more effectively. His attacks upon the hospital in public could not go without a response and the Royal Free was forced to anticipate his every move. 
'Few affairs of international importance have ever excited the popular mind so greatly as has the disappearance of Miss Hickman', remarked the London representative of the Manchester Guardian at the end of August. ${ }^{35}$ Debate about what had happened was heard everywhere and nobody needed 'to be informed on the matter'. Miss Hickman was 'continually discussed' that very day on the reporter's Underground journey between Aldgate and Westminster. Excited speculation about 'the missing lady doctor' was even cited as a contributory factor in fatal heart attacks. An inquest was informed that, just before collapsing, a railway man had been engaged in enthusiastic debate about the disappearance of Miss Hickman. 'Would-be Sherlock Holmes' were encouraging a 'craze for amateur detective work', spurred on by the conflicting and contradictory reports filling the newspapers and journals of the day. ${ }^{36}$ The press, respectable or otherwise, seized upon the Hickman story with relish. Fevered conjecture filled the papers between August and October and the portrait of Sophia Frances Hickman was reproduced all over the country. Mr Hickman would later claim that he had personally issued 35,000 posters. ${ }^{37}$ It is hardly surprising, given Mr Hickman's grasp of publicity, that the inexplicably 'Missing Lady Doctor' was a case which became more fascinating by the day.

With the addition of a substantial reward, Miss Hickmans began to be seen everywhere. The provincial press, stimulated by reports generated by news agencies, sought to add their own local angle to events and encourage searches in their own towns and villages. As the Sheffield Daily Telegraph claimed:

Dr Frances Sophia Hickman's [sic.] face has become familiar all over the country. It was a striking intellectual face, almost mannish, relieved of its severity by the hair parted in the middle, and drawn low over the forehead. One found it in the windows of little out-of-the-way villages, hundreds of miles from London; over it the attraction of ' $£ 200$ reward', and underneath it a description of the clothes. So much publicity 
was given to it, that clues came from all over the country, yet none of them when followed up led to anything tangible. ${ }^{38}$

Amateur detectives stalked single, tall women, who had the misfortune to look a little perplexed by the situation in which they found themselves. In spite of Miss Hickman's unusual appearance, the Coventry Evening Telegraph noted: 'A good many people at the present time are being troubled because they bear a distant resemblance to the famous disappearing Miss Hickman. [. . .] many young ladies are being "shadowed". 39 One example from Leamington will suffice to illustrate the 'craze' stimulated by Sophia Frances Hickman's disappearance. Under the headline 'Miss Hickman Said to Be at Warwick', the local paper could barely conceal its excitement:

No little consternation was caused in Mill St this (Friday) morning, when a report was circulated that Miss Hickman, the missing lady doctor, was in the vicinity. It appears that a respectably dressed young lady was loitering about Mill St shortly after 9 o'clock, and was said to be about the same height and age as the lady wanted. The inhabitants of the thoroughfare became somewhat suspicious as to the lady's identity, and one person actually accosted her and asked if she was Miss Hickman. Meanwhile, a woman apparently desirous of gaining the $£ 200$ reward, made her way to the police station, where she told her tale to Superintendent Ravenhall. The police who been 'had before' suggested that the informant should bring Miss Hickman to the police station. We are also informed that a lady, with her umbrella screening her face, attracted attention on the Castle Hill some two hours later. Up to the time of going to Press, however, Miss Hickman's whereabouts still remain a mystery. ${ }^{40}$

What is fascinating about this particular report is the acknowledgment that this was not the first time the local police had been sent to look fruitlessly for the missing woman. The lack 
of concrete evidence in the case did not prevent lengthy coverage, with frenzied reports such as this, almost every day for two months.

A variety of Miss Hickmans even admitted themselves to asylums for treatment. As Robert Jones, the Resident Physician and Superintendent of Claybury Asylum in Essex, revealed in a research article on 'How To Treat a Case of Insanity', published in December 1903 in the Lancet: 'there are at the present time [persons] admitted into Claybury either as Miss Hickman herself, or those specially commissioned to search for her, or who have elaborate theories [about her]'. ${ }^{41}$ The more sensational the news, the more likely to interest and affect the 'mentally unstable', he continued. In the Journal of Mental Science, Jones elaborated on his cases. Claybury alone had received four people in as many months who either called themselves Miss Hickman, or knew where she was. ${ }^{42}$ As far as the Sophia Hickman case was concerned, 'mentally unstable' people clearly made up a larger percentage of the population than had been previously imagined. Various reasons were put forward for Miss Hickman's sudden disappearance, each becoming more and more fantastic. Some were based on supposed sightings, others from snippets of information given by the family about the missing woman. Not one imagined a love affair, although other explanations were worthy of romantic fiction. ${ }^{43}$ She had been kidnapped by Italians, claimed the Central News, who had the accusation straight from her barrister cousin, Arnold Statham. ${ }^{44}$ Fanatical nuns had escorted her away, suggested an eyewitness letter addressed to her father. ${ }^{45}$ Dozens more letters to Mr Hickman told how his daughter headed for the continent or for Ireland. ${ }^{46}$ As time went on, many papers, such as the Worcestershire Chronicle reported Miss Hickman to be safe and sound, but simply embarrassed because she had so abruptly left her employment. She was undoubtedly lying low because of all the publicity her case had caused. ${ }^{47}$ Others felt her professional obligations were being continued elsewhere. The Gloucester Citizen and the Manchester Evening News reported 
that she had stayed in a Birmingham hotel for more than a week, caring for a female invalid. $^{48}$ Clairvoyants, specially commissioned by pioneering investigative journalist, W.T. Stead, among others, propped up the Hickman family's belief that their beloved Fanny was held against her will, confined to an attic room in a dirty house. ${ }^{49}$ The press alleged that her vanishing had created a marked increase in missing persons in the autumn of 1903. In turn, this phenomenon encouraged speculation about the reasons why apparently content people might want to disappear. The pressures of the modern world and the novels of George Gissing were blamed. According to the Dundee Courier, it was all an effect of the 'silly season'. 50 The Loch Ness Monster certainly had competition this year, it noted; the 'vanishing person' becoming the year's most popular 'craze'.

Unfortunately for the press and also for Miss Hickman herself, the reality was far more serious. It emerged that, on Sunday, 18 October, 1903, some schoolboys were searching for horse chestnuts in Richmond Park. They climbed into the Sidmouth Plantation and stumbled over the decapitated, severely decomposed body of a woman. ${ }^{51}$ While speculation mounted as to her whereabouts, Sophia Frances Hickman had evidently been dead for as long as she had been missed. In a cruel twist of fate, her poor father, who had used the press to try to speed up the finding of his daughter, heard about the discovery of a corpse from a newspaper placard. ${ }^{52}$ The fact that there was now a body did not end the theories about how she had met her end. Abduction and murder topped the list, mainly because of the separation of Miss Hickman's head from her body, which was dwelt on with uncomfortable relish in the press. Described in minute detail, the placement of the corpse and its condition took up pages of report in newspapers across the country. Some wondered about how the head might have become separated from its body, if a vile murder had not taken place. Had it been eaten by rats or had one of the boys kicked it when stumbling across the corpse? ${ }^{53}$ When the inquest on Miss Hickman opened, thousands of interested parties thronged the 
Richmond streets. Due to the state of the body it was presumed impossible to pinpoint with any accuracy how Sophia Hickman had died. The proximity of Richmond Park picnickers meant that the scene where the corpse was found became a detective's nightmare. Bottles littered the area, 'clues' were discovered and then dismissed as simply detritus, and a stray, never to be explained scalpel suddenly appeared in the plantation. A hypodermic syringe, a sponge, a tube of morphine tabloids, and unlabelled medicine bottles hinted at another cause of death than the more gruesome one favoured by the press. ${ }^{54}$ Such a possibility had begun to be voiced just before she had been found. Swiftly after the discovery of the corpse, the Manchester Guardian's London correspondent hinted that Scotland Yard had given up a while ago, aware that the much-circulated posters of Miss Hickman were of no further use. And at least one inquirer had 'come upon information which caused him practically to abandon the search five or six weeks ago ${ }^{55}$ For some, suicide was the evident reason why Miss Hickman had simply vanished, without any trace, from the Royal Free Hospital.

Other items had been noticed by the police when the body was moved which helped in the identification of the victim. Clothes were labelled with Miss Hickman's name and matched those mentioned in the final description of the missing woman. Some evidently dearly cherished objects - a St John's Ambulance cross and a medal for swimming - cast a more troubling light on the woman doctor whose stellar academic achievements were so lauded. ${ }^{56}$ Without any clear indication of Hickman's intentions, the presence, near the body, of small trinkets associated with standard childhood attainment spoke volumes. Pathological evidence confirmed suspicions; murder was discounted because the head's separation had been due not to violence but to the 'ravages' of 'nature'. ${ }^{57}$ From the tiny fraction of remaining liver removed from the corpse, along with supporting testimony that Miss Hickman had recently purchased morphine sulphate, which was not used at the Royal Free, the inquest concluded that she had 'died from poison from morphine sulphate, self- 
administered at a time when she was temporarily insane'. ${ }^{58}$ The mentally and physically strong Dr Sophia Frances Hickman, cheerful and healthy, hardworking and academically talented, was condemned as anything but.

Mr Hickman's insistence from the moment she disappeared was that his daughter had been confronted with unacceptable responsibilities by the Royal Free Hospital. Charles Burt, Chairman of the Weekly Board, had denied outright in a letter to the Times that Miss Hickman had been forced to carry out unpleasant duties in casualty. As a locum, her time was decided by pre-arranged rota, to which she had made neither remark nor demurred in any way. ${ }^{59}$ But, during the inquest, a close friend since childhood, with whom she had dined recently, revealed that nerves were affecting Miss Hickman when she considered the prospect of work at the Royal Free. As The Times reported:

Miss Ada Withell, of Branksome, Lysson-grove, Putney, said she had known Miss Hickman for twenty years. On August 13 the deceased dined with her. She seemed to look forward with pleasure to her new appointment, but was nevertheless nervous about it.

The CORONER - Did she tell you that she feared the responsibility? - Not those exact words, but to that effect.

The CORONER - Did she say, 'If I were a man'? - She said she wished she was a man, because then she could go and get drunk. The witness added that she took this as a joke. ${ }^{60}$

Furthermore, her friend continued, this was not the first time Miss Hickman had expressed doubts about her employment. She feared the work similarly at the Clapham Maternity Hospital, where she had gained her first post. In fact 'she dreaded it'. Only later, when she had grown accustomed to her role did she finally enjoy her experience there. ${ }^{61}$ Everything that medical women were desperate to protect and all that Miss Hickman represented - 
strength of mind and character, ability to carry out professional duties without fear or trembling - crumbled under the weight of Miss Withell's evidence of her friend's longstanding concerns.

'A sort of stage fright' was how Mr Hickman labelled his daughter's evident discomfort at taking on her new responsibilities. ${ }^{62}$ Although she was well-prepared educationally for the role, the actuality of stepping onto the professional stage of the Royal Free paralysed her. While the locum position was not Sophia Hickman's first hospital engagement, and though she would have spent time on Gate as a senior student, something about her current work led to her death. Doubts about the practise of medicine and surgery were, and still are, difficult to articulate or explain for a profession which needs to project calm confidence for the sake of credibility, as well as the patient's trust. ${ }^{63}$ For all her academic prowess, the practical elements of her profession niggled at Miss Hickman. The reaction to these revelations was partly predictable, partly surprising. Even before her body had been found, an anonymous 'Hospital Physician' had written to the Times to draw attention to the evident lack of female 'fitness' for posts in general hospitals. In such institutions, 'tenderly nurtured', 'frail' women might be confronted by the 'drunken and violent' 'brutality' of working-class men. ${ }^{64}$ And, this exposure was all for nothing, because, as women, they would never practise in such an environment, nor encounter adult male patients again. While Sophia Hickman, at five foot nine, could hardly be described as 'frail', as more evidence came to light, it was clear that her impressive frame concealed not only doubts, but a congenital heart problem. Despite her determination to ignore it, by bicycling and walking great distances, she had only three years previously been to see another female doctor about her condition, which had not improved over time. ${ }^{65}$ The inquest revealed further that while there was not any hereditary mental illness in the Hickman family, a younger sister of the dead woman had 'broken down' and been forced to leave her studies. ${ }^{66}$ Both mental and 
physical frailties had dogged Miss Hickman, despite outward appearances. Although the Lancet had concluded in 1869 that 'medical women' were 'an established fact that cannot be gainsaid or ignored', the death of Miss Hickman encouraged a resurgence of debate about female delicacy. ${ }^{67}$ The medical woman had become the lady doctor again in the eyes of the press.

General unfitness to practise because of one woman's disappearance was instantly dismissed by female members of the profession and their supporters. The first woman to qualify as a doctor in Britain and the recently retired Dean of the LSMW, Elizabeth Garrett Anderson, responded to 'A Hospital Physician's' assumption that women were neither capable of practising nor indeed required by patients of either sex. In a riposte to 'A Hospital Physician', who she compared to an old lady recommending that the loss of one explorer should mean the end of all exploration, Garrett Anderson dismissed his comments out of hand. If women did not want to be examined by their own sex, why were the waiting rooms of institutions such as the female-run New Hospital for Women overflowing with those desperate to consult medical women? Furthermore, to exclude women from the vital part of their clinical training would be unjust. ${ }^{68}$ An unnamed 'Surgeon' from the Royal Free also responded to 'A Hospital Physician's' recommendations with scorn. The 'robust health and excellent spirits' of Sophia Hickman did not indicate any concern about her responsibilities and she was not under any 'strain' because of her position. ${ }^{69}$ Not a single student had broken down mentally at the LSMW in its nearly thirty-year history and neither had any of those who had qualified from the school succumbed when they began to practise. Instead of focusing on the blame which should be attached to those on the managing boards of institutions which had appointed women to resident posts, why not focus on the success of those female doctors who had taken up the challenge? Indeed, the 'Surgeon' concluded, the holders of such positions could hardly be considered to have 'deteriorated either physically, 
mentally, or morally'. The recent momentous decision to hand control of the gynaecological department of the RFH to the surgeons Mary Scharlieb and Ethel Vaughan had seen the numbers of out-patients dramatically increase, indicating a ready and growing market for women who wanted to consult their own sex. ${ }^{70}$ If 'A Hospital Physician' visited the 'crowded casualty department' of the RFH he would not find many who objected to being treated by a woman; prejudice was neither widespread nor 'due to anything but ignorance of the facts', which were easily dispelled. And, for the final point, the 'Surgeon' resurrected an old comparison, used from the start of the campaign to admit women to the medical profession. The 'realities of life' and the daily encounter with the 'disagreeable' were, of course, experienced by anyone employed in a hospital as a nurse. 'Lady' nurses were of a similar class and standing to female medical students and doctors. Why should it be entirely becoming for them to witness certain 'degrading' scenes, but not for their medical counterparts to see the same? Women employed in hospitals, argued the RFH 'Surgeon', could cope admirably, both with their patients and with the demands of their profession.

Those who knew Miss Hickman well sought again and again to deny that she could have possibly committed suicide. Their upholding of the no weakness mantra is evident in statements made after the discovery of the body. On the witness stand at the inquest, Dr Janet Campbell, for whom Sophia Hickman had been acting as locum, remarked that the dead woman had not seemed 'to be at all nervous about her duties', understanding 'clearly what she had to do'. Dr Campbell had escorted her replacement around the wards for a few days to introduce her to the cases which would come under her control, so she was familiar with her tasks. If Miss Hickman had felt worried in any way, then she did not need to bear all the responsibility, as she was working under Mr Percy Legg, Assistant Surgeon, whom she could consult in any difficulty. ${ }^{71}$ An unnamed 'lady surgeon' of the Clapham Maternity 
Hospital, interviewed in the press, was equally stunned at any possibility of suicide over mere quotidian responsibilities:

“"Miss Hickman was probably stunned or attacked from behind. Of course a woman such as she would never have fallen without a fearful struggle had she been face to face with her adversary. [. . .] Everyone at the Clapham Maternity Hospital shares my opinion in the matter. Miss Hickman was the last person on earth to take her own life", 72

Margaret Joyce, who had worked with the dead woman, agreed. She 'had never known Miss Hickman to be nervous, she was physically powerful' and 'few persons were so happy'. ${ }^{73}$ For 'One of the Surgeons to the Royal Free Hospital',

[i]t is quite true that cases of mental breakdown do occur occasionally among newlyqualified practitioners, from the weight of responsibility thrown upon them. It is within my own knowledge that two such cases have occurred within the last five years at one of the larger London hospitals; but in both cases the victims were men, not women. ${ }^{74}$

All either knew or knew those who associated with Sophia Hickman. None could believe that such a friend and colleague could kill herself, but, equally, none was willing, in the first place, even to conceive that medical women suffered from suicidal thoughts. If anyone was likely to do away with themselves it was the male professional. The early twentieth-century female doctor suffered from none of the difficulties that had beset her mid-nineteenthcentury predecessor. In an address to the LSMW at the beginning of the 1910 academic year, the RFH surgeon, E.W. Roughton, stressed that the path to success had been made 'smooth and easy' for the contemporary female aspirant to a medical career. ${ }^{75}$ Life was simple in comparison to that of the 'brave women' who selflessly battled entrenched prejudice over thirty years before to clear the way for future generations. Suicide was, 
therefore, the ultimate discrediting of medical women's ability to cope with difficult situations. And, more vitally, it proved detractors of female doctors' fragility correct. For other representatives of the medical world, however, it was a likely explanation and one which was more to do with the susceptibility of the profession itself than specifically female frailty.

Both the Lancet and the British Medical Journal shook their heads wisely at the outcome of the Sophia Hickman case. At times, indeed, there was a sad weariness to their coverage. Each periodical acknowledged the brilliance of Miss Hickman's student achievements, but there was also an awareness shown that initial success and hopes of promise did not always translate into an equally sparkling career. As the $B M J$ concluded:

It is too well known that many a brilliant student in arts, science, and medicine has failed in after-life to do justice to his earlier reputation. It may be that his student days have been absorbed in theoretical studies, and that nothing is left to lighten the practical work which succeeds graduation and thus a state of over-training induced which makes for non-success in the hard race for life. ${ }^{76}$

The Lancet resorted to drama:

The fears which may and do affect the younger untried members of our profession are very real. Every medical practitioner has experienced such fears and the time of their occurrence seems very dark. Most men overcome them but some fall by the way. Each and all of us when confounded with a tragedy like the present may take to himself the words of LEAR and pray: -

'Oh, let me not be mad, not mad, sweet heaven! ${ }^{77}$

By emphatically drawing attention to kinship rather than difference, the main medical periodicals did not comment on Miss Hickman's femaleness as the cause of her suicide, but rather pinpointed unbearable professional pressures, to which all could relate. 
Indeed, the $B M J$ went one step further and mounted a surprisingly vehement defence of medical women. The piece is worth quoting in full:

It has been assumed by one of our lay contemporaries that there is a moral to be drawn from this sad case, and that this moral is that women should not be exposed to the strain to which Miss Hickman succumbed. We fail to see that this contention is justified, as unfortunately we have too many recorded cases in the history of legal medicine in which male practitioners have taken their own lives owing to being unable to endure the responsibilities which had been thrown upon them in the course of their professional work. Women have for a long period now been members of the medical profession with great credit to themselves, and to suggest that all women are unfit to practise medicine because one of their weaker sisters has fallen by the way and failed in her self-appointed task is to draw a false conclusion from the particular to the general. ${ }^{78}$

For the $B M J$, it was the weak individual who had succumbed to the pressures of professional life, rather than all medical women being innately unfit. But as both the Lancet and the $B M J$ recognised, weakness could attack at any point and even the most brilliant were not immune. Consequently, if the best can become infected with self-doubt, or a 'sort of stage fright', as E.F. Hickman so aptly phrased it, fear of failure was inevitable in the profession.

\section{Conclusion}

The Sophia Hickman case revealed that, by 1903, confidence in women doctors was still shaky in some instances, but strengthening in others. For all Garrett Anderson's claims that patients required and supported medical women, the most effective bolstering of their cause came from the main medical periodicals. In The Evolution of British General Practice, Anne Digby notes that in the 1890 s, '[a] sign of a more general change in society's opinion 
towards women's entry to medicine, however, was indicated by a sympathetic tone in the non-medical press'. Medical men, on the other hand, were persistent in their prejudice against their female counterparts. This fluctuated, but was especially hardened in times of unemployment in the profession. As this article has shown, the Sophia Hickman case implied the opposite. ${ }^{79}$ Indeed, the most sympathetic tone towards the plight of the "missing lady doctor' can be found not in the lay papers, nor even in the statements of her female colleagues, but in the major medical weeklies. This defence came at a time when 'grave' questions were being asked about the numbers of medical professionals in relation to the population; there were too many doctors and not enough fee-paying patients for them all to survive adequately. ${ }^{80}$ These circumstances alone should have seen feelings running high against female invaders. Yet, only a few months before the death of Sophia Hickman, W. Gordon explored 'The Overcrowding of the Medical Profession' in the BMJ. This was an article supplemented by some depressing information from the Registrar General, which placed the profession at the top of self-inflicted mortality statistics. ${ }^{81}$

Table III - Showing Effects of Overstrain of Medical Men. Comparative Mortality Figures, 1890-92 (Supplement to Registrar General's Report, 1897)

$\begin{array}{lrccr}\text { Occupation } & \text { All Causes } & \text { Alcohol } & \text { Nervous Diseases } & \text { Suicide } \\ \text { Occupied Males } & 953 & 13 & 82 & 14 \\ \text { Clergymen } & 533 & 2 & 69 & 7 \\ \text { Lawyers } & 821 & 12 & 104 & 18 \\ \text { Schoolmasters } & 604 & 8 & 71 & 15 \\ & & & & 41\end{array}$


Gordon noted, in emphatic italicisation, that 'The death rate from suicide is enormous': 'elaborate clinical methods' and poverty root causes. Though the reasons for suicide and depression change with context and individual, there is plenty of support today for the young medical professional. The British Medical Association, for example, advises its new professional recruits generally, on 'coping with situations for the first time' and 'real life advice' from slightly older peers about preparing for vicissitudes, how to approach a sick patient or how to break bad news for the first time. Knowledge that help is available and taking advantage of that assistance when it is needed are, however, tragically separate things. ${ }^{82}$ The chasm between these two claimed Sophia Frances Hickman, as it has many before and since. For all the speculation and scandal which erupted after Miss Hickman left the Royal Free Hospital one summer afternoon, she was one of many and was embraced as such by her male colleagues. Ironically, it was her female colleagues who sought to deny any underlying fragility. In the case of Sophia Frances Hickman, the medical profession displayed unusual unity, finding common ground in the tragic circumstances of the suicide of a promising young doctor.

\section{Notes and References}

${ }^{1}$ The only other published account of the Hickman disappearance is brief but very thorough. It links the case particularly with the context of early twentieth-century concerns about mental health. See Susan Collinson, 'The Case of the Disappearing Doctor: Women, Suicide and Insanity at the Turn of the Century', Psychiatric Bulletin, 14, 1990, 83-86. 
2 'Women's Future in Medicine. Achievements and Opportunities', Hospital, 4 September 1915, pp.477-478; p.477.

${ }^{3}$ Countrywide reaction to 'The Discovery of Miss Hickman', collated in Evening Telegraph, Tuesday 20 October 1903, p.3.

${ }^{4}$ C.L. McCluer Stevens, From Clue to Dock, London, 1927, p.78.

${ }^{5}$ McCluer Stevens, From Clue to Dock, p.86.

${ }^{6}$ The Sydney Morning Herald, for example, reported on the outcome of the case. See articles published about the fate of Miss Hickman on Wednesday, 21 October 1903, 9 and Friday, 23 October, 1903, 5. New Zealand's The Southland Times also wondered 'Will it Ever be Unravelled?', 19191, 31 October 1903, p.2.

For a précis of the work of news agencies, see the entry in Dictionary of NineteenthCentury Journalism, Ghent and London, 2009, pp.450-451.

${ }^{7}$ See Lynne A. Amidon, An Illustrated History of the Royal Free Hospital, London, 1996.

${ }^{8}$ Draft Report pasted into the Meeting of the Council of the London School of Medicine for Women, Wednesday, 16 December 1903, Royal Free Hospital Committee of Management Minutes, Vol. 6, 1891-1906, London Metropolitan Archives, H71/RF/A/02/01/006.

${ }^{9}$ Letter from E.F. Hickman to the Editor of the The Times, 'The Disappearance of a Lady Doctor', The Times, 37164, Thursday, 20 August 1903, 9.

10 'A Woman Doctor: Her Training and Her Chances', Daily News, 6 July 1910, in London School of Medicine for Women Press Cuttings Volume IV, London Metropolitan Archives, $\mathrm{H} 72 / 2 \mathrm{M} / \mathrm{Y} / 02 / 004$.

11 'Is the Lady Doctor a Failure', BMJ, 1:2144, 1 February 1902, p.287.

12 Christopher Lawrence, 'Incommunicable Knowledge: Science, Technology and the Clinical Art in Britain 1850-1914', Journal of Contemporary History, 20:4, October 1985, pp.503-520. 
${ }^{13}$ Reproduction of the leading article from the Daily Telegraph, Tuesday 3 October 1916, in London (Royal Free Hospital) School of Medicine for Women Magazine [L(RFH)SMWM], 11:65, November 1916, pp.98-101; p.99.

${ }^{14}$ There is a great deal of literature on the early campaign against women's challenge to the medical profession. See, for just a couple of classic examples, E. Moberley Bell, Storming the Citadel: The Rise of the Woman Doctor, London, 1953, and M.A. Elston, 'Women Doctors and the British Health Service: A Sociological Study of their Careers and Opportunities', PhD thesis, University of Leeds, 1986.

${ }^{15}$ Letter from E.F. Hickman to the Editor of the The Times, 20 August 1903. Description issued across the country via newspaper reports and posters.

${ }^{16}$ H.W. Sharpin, 'Topics of the Day: An Address Delivered at the Combined Annual Meeting of the South Midland and Cambridgeshire and Huntingdonshire Branches', BMJ, 2:813, 29 July 1876, pp.144-145.

${ }^{17}$ Joan and Jill, 'Our Ladies' Letter', Reading Mercury, Saturday, 19 September 1903, p.9.

${ }^{18}$ Letter from E.F. Hickman to the Editor of the The Times, 20 August 1903.

19 'Hickman Inquest: What a Lady Doctor Said', Portsmouth Evening News, Friday, 13 November 1903, p.5.

${ }^{20}$ For the complexity of advice about girls' health at the turn of the twentieth century, see Hilary Marland, Health and Girlhood in Britain, 1874-1920, Basingstoke, 2013.

21 'Statement of Patients Under Treatment', The Seventy-Sixth Annual Report of the Royal Free Hospital for the Year Ending December $31^{\text {st }}$ 1903, London, 1904, p.32.

${ }^{22}$ Anon., 'Gate t.d.s (A Reminiscence of 1906)', L(RFH)SMWM, 38, October 1907, pp.805$806 ;$ p.806.

${ }^{23}$ Letter to the editor from 'A Lover of Truth', L(RFH)SMWM, 23, October 1902, pp.97-99; p.98. 
${ }^{24}$ Letter from Charles Burt to the Editor, The Times, 37175, Wednesday 2 September 1903,

4.

${ }^{25}$ Letter from E.F. Hickman to the Editor of the The Times, 20 August 1903.

26 'Why Miss Hickman Left the Hospital', The Star, 28 August 1903, pasted into the Special Meeting of the Weekly Board of the Royal Free Hospital, Thursday, 3 September 1903, RFH Weekly Board Minute Book, Vol. 15: 1901-1906, London Metropolitan Archives, $\mathrm{H} 71 / \mathrm{RF} / 1 / 03 / 01 / 014$.

27 The need to maintain links between the pioneers and the present runs though Isabel Thorne's Sketch of the Foundation and Development of the London School of Medicine for Women, Hunter Street, Brunswick Square, W.C., London, 1905.

${ }^{28}$ For more on dissension between different generations of medical women, see Claire Brock, 'The Fitness of the Female Medical Student, 1895-1910', in Francesca Scott, Kate Scarth and Ji Won Chung (eds), Picturing Women's Health, London, 2014.

${ }^{29}$ Joseph Cunning, 'The Disappearance of Miss Hickman', The Times, 37172, Saturday, 29 August 1903, p.7.

${ }^{30}$ J. Percy Watson, 'The Disappearance of Miss Hickman', The Times, 37173, Monday, 31 August 1903, p.8.

${ }^{31}$ Letters from Charles Burt and E.F. Hickman, both dated 1 September, 'The Disappearance of Miss Hickman', The Times, 37175, Wednesday, 2 September 1903, p.4.

${ }^{32}$ Anne Digby, Making a Medical Living: Doctors and Patients in the English Market for Medicine, 1720-1911, Cambridge, 1994.

${ }^{33}$ Letters from Charles Burt and E.F. Hickman, both dated 1 September, 'The Disappearance of Miss Hickman', The Times, 37175, Wednesday, 2 September 1903, p.4.

${ }^{34}$ Special Meeting of the Weekly Board of the Royal Free Hospital, Thursday, 3 September 1903. 
35 ‘Our London Correspondence’, Manchester Guardian, 28 August 1903, p.4.

36 'The Missing Lady Doctor. What “Little Italy” Thinks', Manchester Guardian, 31 August 1903, p.5.

37 'Miss Hickman's Fate. The Doctors' Opinion', Manchester Guardian, 21 October 1903, p.12.

38 'The Missing Lady Doctor', Sheffield Daily Telegraph, Tuesday, 20 October 1903, p.7.

39 ‘Topics of the Day', Coventry Evening Telegraph, Friday, 25 September 1903, p.2.

40 'Warwick', Leamington Spa Courier, Friday, 25 September 1903, p.8.

${ }^{41}$ Robert Jones, 'How to Treat a Case of Insanity', Lancet, 162:4191, 26 December 1903, pp.1775-1781; p.1776.

${ }^{42}$ Dr Robert Jones' response to R.S. Stewart's, 'The Mental and Moral Effects of the South African War, 1899-1902, on the British People', Journal of Mental Science, 50:208, January 1904, pp.1-13; p.11.

${ }^{43}$ Only The Southland Times remarked that she 'had no love affair on hand', 31 October 1903, p.2.

44 ‘The Missing Lady Doctor', Manchester Guardian, 28 August 1903, p.5

45 'The Disappearance of Miss Hickman', The Times, 37206, Thursday 8 October 1903, p.10.

46 ‘Our London Correspondence', Manchester Guardian, 28 August 1903, 4.

47 'The Disappearance Epidemic', Worcestershire Chronicle, Saturday 5 September, p.8.

48 'The Missing Lady Doctor', Gloucester Citizen, Tuesday 8 September 1903, p.4; Manchester Evening News, p.3.

${ }^{49}$ McCluer Stevens, From Clue to Dock, pp.80-81.

50 ‘The Silly Season', Dundee Courier, Tuesday 8 September, 1903, p.4.

${ }^{51}$ The schoolboys were rewarded with the money put up by Mr Hickman and the RFH for information as to Miss Hickman's whereabouts. Mackinney, who first informed the police, 
received $£ 10$ and the rest was invested into Government Stock. This was to be divided between Mackinney (£90) and another two boys who were with him (£50 each), and kept until they were twenty-one. The money could be utilised by the trustees - the Mayor and Vicar of Richmond - for 'instruction, apprenticeship or advancement' during their minority. 'Real advantage' could therefore be obtained as compensation for the boys' unfortunate discovery. See 'Editorial', L(RFH)SMWM, 26 (1903), pp.263-264.

52 'The Discovery of Miss Hickman', Evening Telegraph, Tuesday, 20 October 1903, p.3.

${ }^{53}$ See, for just one example of such speculation, the Sheffield Daily Telegraph, Tuesday 20 October 1903, p.6.

54 'Medico-Legal and Medico-Ethical: Inquest on Miss Hickman, M.D.', BMJ, 2:2237, 14 November 1903, p.1312.

55 'Our London Correspondence (By Private Wire)', Manchester Guardian, 20 October 1903, p.6.

${ }^{56}$ Details reported across the country. See, for example, 'Our London Letter: The Late Miss Hickman', Gloucester Citizen, Tuesday, 20 October 1903, p.3.

57 'The Death of Miss Hickman', Lancet, 162.4186, 21 November 1903, pp.1443-1444; p.1443.

${ }^{58}$ See, for example, 'Medico-Legal and Medico-Ethical: Inquest on Miss Hickman, M.D.', BMJ, 2:2238, 21 November 1903, p.1381, which itself quotes from the Daily Telegraph's coverage of the case.

59 'The Disappearance of Miss Hickman', The Times, 37175, Wednesday, 2 September 1903, p. 4 .

60 'The Death of Miss Hickman: The Inquest', The Times, 37231, Friday, 6 November 1903, p. 4 . 
${ }^{61}$ The witness appears in various accounts either as Miss Withell or Miss Woodhall. For these comments see 'Inquest on Miss Hickman', BMJ, 14 November 1903.

62 'The Discovery of Miss Hickman', Evening Telegraph, Tuesday, 20 October, 1903, p.3.

${ }^{63}$ On patient trust in surgeons see Sally Wilde, 'Truth, Trust, and Confidence in Surgery, 1890-1910: Patient Autonomy, Communication, and Consent', Bulletin of the History of Medicine, 83:2, 2009, 302-330.

For a rare example of a public acknowledgment of fear, see Henry Marsh's recent Do No Harm: Stories and Life, Death and Brain Surgery, London, 2014.

64 'Lady Doctors in General Hospitals', The Times, 37212, Thursday, 15 October, 1903, p.13.

65 'The Death of Miss Hickman', Times, 37219, Friday, 23 October, 1903, p.8, quoting a letter from Dr May Thorne to Mr Hickman.

66 'Miss Hickman's Death. Verdict of the Coroner's Jury', Manchester Guardian, 13 November 1903, 10.

67 'Medical Annotations', Lancet, 94:2414, 4 December 1869, p.783.

68 'Medical Women in General Hospitals', The Times, 37214, Saturday, 17 October 1903, p.4.

69 'One of the Surgeons to the R.F.H.', 'Lady Doctors and General Hospitals', The Times, 37215, Monday, 19 October 1903, p.14.

${ }^{70}$ This was indeed an accurate statistic. From 541 in 1902, the total number almost doubled to 1069 a year later. See The Seventy-Six Annual Report of the Royal Free Hospital for the Year Ending December 31 ${ }^{\text {st }}$, 1903, London, 1904.

71 'Miss Hickman's Death. Result of Dr Stevenson's Examination', Manchester Guardian, 6 November 1903, p.5. 
72 'Theory of Miss Hickman's Death. Attacked from Behind', Hull Daily Mail, Wednesday, 21 October, 1903, p.3.

73 'The Death of Miss Hickman: Conclusion of the Inquest', The Times, 37237, Friday 13 November 1903, p.5.

74 'Lady Doctors and General Hospitals', The Times, Monday, 19 October, 1903.

75 E.W. Roughton, 'Opening Address at LSMW: Women's Sphere in Medicine', L(RFH)SMWM, 47, October 1910, pp.292-306; p.293.

76 ‘The Late Miss Hickman, M.D.', BMJ, 2:2238, 21 November 1903, p.1356.

77 'The Death of Miss Hickman', Lancet, 21 November 1903, p.1444.

78 'The Late Miss Hickman, M.D.', BMJ, 21 November 1903.

${ }^{79}$ Anne Digby, The Evolution of British General Practice 1850-1948, Oxford, 1999, p.156.

${ }^{80}$ Robert R. Rentoul, 'The Overcrowding of the Medical Profession', $B M J, 1: 2212,23$ May 1903, p.1236.

${ }^{81}$ W. Gordon, 'The Overcrowding of the Medical Profession', BMJ, 1:2211, 16 May 1903, pp.1152-1153; p.1153.

82 http://bma.org.uk/developing-your-career/foundation-training/real-life-advice [accessed 18 May 2015]. When I discussed the Hickman case with medical students, they all professed themselves aware of the support available, but were also convinced that it was not something they, personally, would ever need to assist them in completing their degree. 